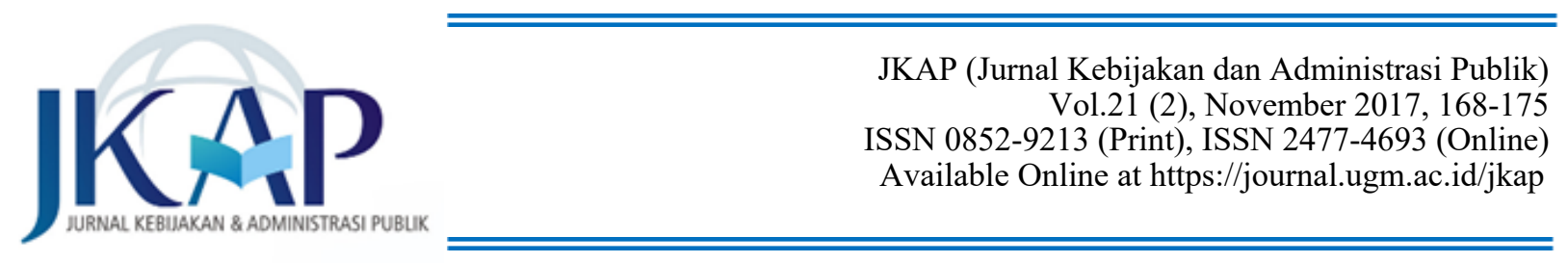

\title{
The Impact of Land Conversion on Income and Food Security Status for Farmer Households in 5 Villages in Temon Sub-District, Kulon Progo Dis- trict, 2017
}

\author{
Anisa Nurpita \\ Economics and Business Department Vocational School, Universitas Gadjah Mada \\ anisanurpita@ugm.ac.id \\ Latri Wihastuti \\ Economics and Business Department Vocational School, Universitas Gadjah Mada \\ latri.wihastuti@ugm.ac.id \\ Ike Yuli Andjani \\ Economics and Business Department Vocational School, Universitas Gadjah Mada \\ ikeyuliandjani@ugm.ac.id
}

\begin{abstract}
Preparation for the construction and development of NYIA airport in Temon sub district, Kulon Progo district, D.I. Yogyakarta province has caused displacement of people for their land, including farmers. Farmers affected are located in five villages that include Jankaran, Palihan, Sindutan, Glagah and Kebon Rejo. The objective of this resrarch is to analyze the impact of land conversion on farmer household incomes and food security status. The research used both primary and secondary data. Primary data was collected using structured questionnaire. Analysis of data was based on descriptive statistics and test of differences between paired samples. Results showed that land conversion has had a negative and significant influence on incomes of affected farmer households. The decline in household income of farmers in 5 villages in Temon sub district among other factors, is attributable to the reduction in farming land. Secondly, consequently, loss of farmer household income aggravated the vulnerability of the affected households to food insecurity. The number of farmer households that experienced food insecurity increased from 87 percent of all farmer households prior to land conversion to 90 percent after land conversion. Conclusions formed the basis for several policy recommendations to mitigate and if possible overcome the problem.
\end{abstract}

Keywords: farmer household, income, land conversion, vulnerability to food insecurity 


\section{INTRODUCTION}

Heavy dependence of a large section of Indonesian population on agriculture in general and food crops growing in particular, makes land conversion an issue that is serious cause for concern. Land conversion is influenced by forces of supply of, and demand for, land, where supply or availability of land is fixed or limited, while demand is unlimited. Lestari (2009) defines land conversion as changing part or all of land from the initial use (as designated) to another use which has potential to generate adverse effects on the environment and potential of the land. Land conversion also refers to the change in the use of land to another use as a result of other factors which by and large relate to an increase in demand for land use that is attributable to an increase in the population and improvement in the quality of living.

The construction and development of New Yogyakarta International Airport (NYIA) in Kulon Progo district, which is one of the mega projects that are currently being implemented by the central government requires the conversion of land. In accordance with IPL Governor No.68/ KEP/2015 issued on 31 March 2015 on the procurement of land along the Coast of Temon sub district, Kulon Progo district (5 villages that include Jangkaran, Sindutan, Glagah, Palihan and Kebonrejo). Land that is the focus of clearing for the future development of the new international airport comprise land that is the property of individuals as well as that that belongs to the Pakuaalam (Pakualaman Ground). Of the total land that is designated for the new airport, 645.63 $\mathrm{Ha}, 466.73 \mathrm{Ha}$ is private belongs to members of public, and $178.90 \mathrm{Ha}$ is pakualaman ground. The conversion of land from farming to becoming an international airport, industrial area, and residence is estimated to hover $300 \mathrm{Ha}$. Temon is a sub district that is at the center of the land conversion exercise to clear land for the construction and development of NYIA.

Loss of source of livelihood for farmer households, loss of farm income and employment, and inability to take advantage of opportunities that relate to farming, are some of the adverse effects of land conversion on the affected population. The decrease in farm income in turn adversely affects the purchasing power of the affected population, and by extension their access to food.

According to Hernanto (1994), income is a form of reward for investment in land, labor, and capital in the farming activity. The wellbeing of farmers increases if they are able to generate an increase in the value of their produce by using same cost of input or if they the value of their output remains the same but the cost of inputs used decreases. Thus improvements in prices of farmer produce and decrease in cost of inputs are key factors that influence farmer welfare. To that end, variations in product and factor prices and productivity induces variations in farmer incomes. Price and productivity are the key factors that cause uncertainty for farming activities (Soekartawi, 1995).

Farm households which comprise at least one member undertake farming activities that produce agricultural produce that is partially sold or exchanged for income or profits with the risk borne by the farmers. Farming activities include growing agricultural commodities, rearing livestock, rearing and fresh water and brackish fish, and becoming fisher folks. The index is compiled on the basis of three dimensions that include availability of food, access to food, and utilization of food. Physical, economic, and social access represent the food affordability dimension. A number of indicators are used to measure food security.

According to Sulistyawati (2014), macro and micro factors influence land conversion. Macro level factors include number of industries and contribution of nonagricultural GDP to national GDP. Meanwhile micro level factors include number of dependents in farmer households, cost of production, and the proportion of farm income to total household income. Land conversion in turn has adverse impact on farmer household income and quality of rice production.

Hendrawan and Dewi (2016) in a research on the Impact of conversion of farm land to residential area on farm household income in Puncel village, Deket, Wetan, Lamongan, found that in the aftermath of land conversion some individual continued to be farmers, others became workers, and not a few became unemployed. Nonetheless, 
Anisa Nurpita, Latri Wihastuti and Ike Yuli Andjani — The Impact of Land Conversion on Income....

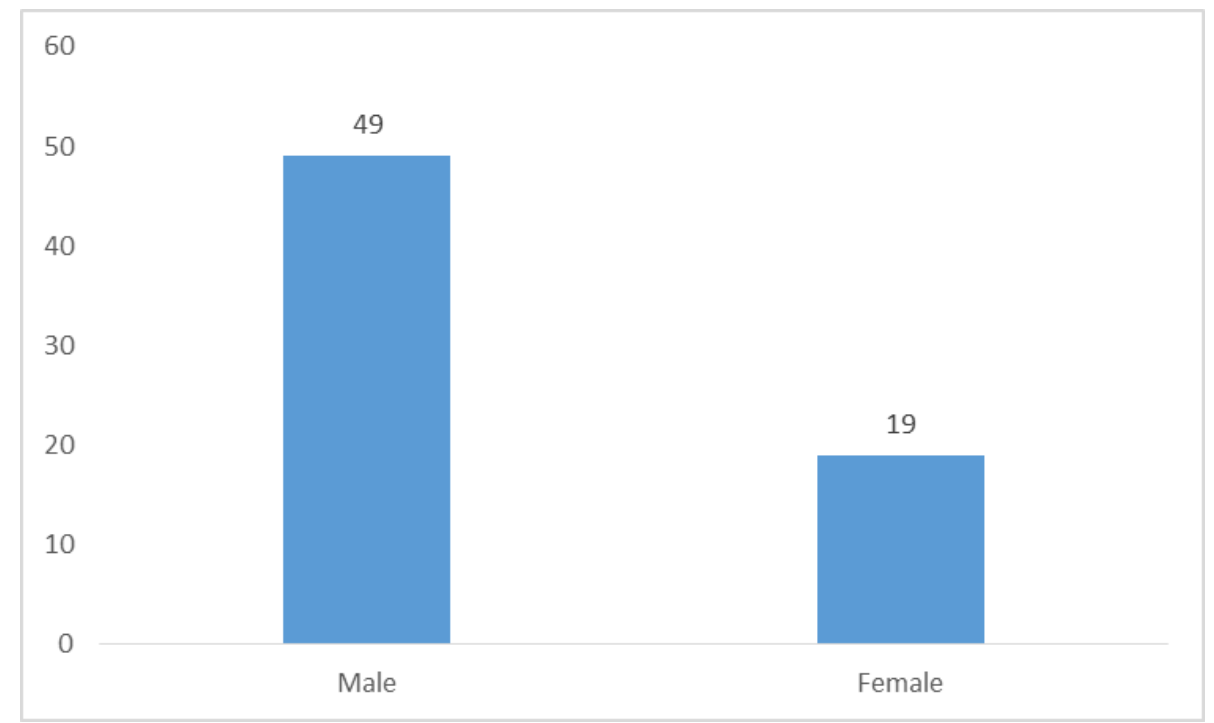

Figure 1. Number of respondents by gender in 5 villages in Temon sub district Source: Data analysis

the majority of those affected continued to be farmers with a change in status from farming their own land to labor for hire (laborers). In relation to the impact of land conversion on income, of the total 42 informants, 38 of them $(83.4 \%)$ perceived their income to have decreased; 3 informants perceived their income not to have registered no change. Nonetheless, one informant, who was a café owner who is also dabbling as a school teacher, registered an increase in income.

In a research conducted by Sulistyaningsih and Puryantoro (2012) on the impact of land conversion of farm land to residential area on farmer income. Using a sample of 13 plots of land that were converted into residential area, results showed that farmer income experienced a decrease in the wake of land conversion. (Kamilah, 2013) in a research on the factors that analyzed the determinants of land conversation, economic value of land before and after land conversion and the impact of land conversion on farmer income in Bekasi City, showed that five factors that influence include the age of the farmer, land area before and after land conversion, net income before land conversion, land productivity and farming experience of the farmer. The research did not find education and number of dependents important in influencing land conversion. With respect to the value of land rent generated after land conversion, the research estab- lished that land rent higher after land conversion from farm land into industrial and residential use. Land conversion induced a decrease of 46 percent in farm income.

Purwaningsih, Sutomo, and Istiqomah (2015) conducted a research on the impact of land conversion on food security for farmer households in The objective of the research was to identify sources of income and determine factors that influence expenditure and access to food for both farmer households involved in land conversion and those that were not. Results of the research showed that farmer households that incomes of most of farmer households not involved in land conversion was higher than that form farmer households involved in land conversion. Land conversion, age, and number of members in a household, assets owned, had significant influence access to food. Nonetheless farm income and household income did not have significant influence on household access to food.

The difference between previous research and this one lies in the fact that it was conducted in a location that is also different. Land conversion with the purpose of availing land for the development of public utilities and infrastructure is an issue that remains relevant and center of debate in public discourse. 
Table 1. Distribution of Household income in 5 villages in Temon sub district

\begin{tabular}{clcc}
\hline No & \multicolumn{1}{c}{ Income } & Number & Percentage (\%) \\
\hline 1 & $\mathrm{y}<1,000,000$ & 22 & $32.35 \%$ \\
\hline 2 & $1,000,001<\mathrm{y} \leq 1,500,000$ & 9 & $13.24 \%$ \\
\hline 3 & $1,500,001<\mathrm{y} \leq 2,000,000$ & 7 & $10.29 \%$ \\
\hline 4 & $2,000,001<\mathrm{y} \leq 2,500,000$ & 9 & $13.24 \%$ \\
\hline 5 & $2,500,001<\mathrm{y} \leq 3,000,000$ & 3 & $4.41 \%$ \\
\hline 6 & $\mathrm{y}>3,000,001$ & 18 & $26.47 \%$ \\
\hline & Total & 68 & $100.00 \%$ \\
\hline
\end{tabular}

Source: Data analysus

\section{RESEARCH METHODS}

The population for the research comprised all households in 5 villages affected by land conversion inter alia Jangkaran, Sindutan, Glagah, Palihan and Kebonrejo, Temon sub district, Kulon Progo district, which is 2685 . The following formula, which is based on Krejcie and Morgan (1970; 607-610) was used to determine a sample. Thus, research a structured interview technique to collect the data.

$$
s=X^{2} N P(1-P): d^{2}(N-1)+X^{2} P(1-P)
$$

Where by:

$\mathrm{s} \quad$ : Number of respondents

$\mathrm{X}^{2} \quad$ : chi-square Table value

$\mathrm{N}$ : Population

$\mathrm{P} \quad$ : Proportion of the Population

d : Tolerance limit

Calculation of the formula was based on $10 \%$ tolerance produced a sample of 66 farm households. Proportional random sampling was used to select respondents that were surveyed.

Meanwhile, analysis of descriptive statistics was used based on test of difference between paired sample means. In addition, presentation of descriptive statistics was used to supplement analysis results. The research examined two hypotheses, that is: i) there is a difference in the income of farmer holds before and after land conversion; and ii) there is a difference in farmer household expenditure before and after land conversion.

\section{RESULTS AND DISCUSSION}

The sample comprised 72 percent male, and 28 percent female (Figure 1). In light of that, the number of males in the sample was larger than that of females due to the fact that farmers are predominantly males in the five villages that were surveyed.

Education is one of the factors that influences household vulnerability to food insecurity. Based on education attainment, 62 percent of respondents had elementary and junior education as the highest education level. This underscores lack of appreciation of the importance of higher education in the 5 villages that served as research location for this study. Low education attainment among respondents has important implication for the type of employment for people in the 5 villages studied. In other words, low education attainment means that most of the people in the 5 villages studied are farmers. Moreover, farmers in the 5 villages studied can be described as modern. Figure 2 shows percentage of respondents by level of education attainment.

Farmer household income in the 5 villages the study covered was in the order of Rp. 1,971,078 per month, with the income per month ranging from Rp.0 per month to Rp. 9,000,000 per month. Of the households covered in the survey, 33.33 percent had an income per month below Rp. 1,000,000, while 10.29 percent of households had income per month that fell in the $\mathrm{Rp}$. 2,000,001-Rp. 2,500,000 range. Thus, income per month for farm households in the 5 villages covered in the survey is still below 
Anisa Nurpita, Latri Wihastuti and Ike Yuli Andjani - The Impact of Land Conversion on Income....

Table 2. Result of the Paired sample t-test on the impact of land conversion on farmer household income in 5 villages in Temon sub district

\begin{tabular}{|c|c|c|c|c|c|c|c|c|c|}
\hline & & \multicolumn{5}{|c|}{ Paired Differences } & \multirow[t]{3}{*}{$\mathbf{t}$} & \multirow[t]{3}{*}{ df } & \multirow{3}{*}{$\begin{array}{l}\text { Sig. (2- } \\
\text { tailed) }\end{array}$} \\
\hline & & \multirow[t]{2}{*}{ Mean } & \multirow[t]{2}{*}{$\begin{array}{l}\text { Std. Devia- } \\
\text { tion }\end{array}$} & \multirow[t]{2}{*}{$\begin{array}{l}\text { Std. Error } \\
\text { Mean }\end{array}$} & \multicolumn{2}{|c|}{$\begin{array}{l}95 \% \text { Confidence Interval of } \\
\text { the Difference }\end{array}$} & & & \\
\hline & & & & & Lower & Upper & & & \\
\hline \multirow{3}{*}{ Pair 1} & $\mathrm{TP}$ _before & & & & & & & & \\
\hline & - & 286519,608 & 691306,220 & 83833,193 & 119187,854 & 453851,362 & 3,418 & 67 & ,001 \\
\hline & TP_after & & & & & & & & \\
\hline
\end{tabular}

Source: Data analysus

KulonProgo district minimum wage. Details of income per month by farm households in 5 districts covered by the survey appear in Table 1.

Farmer household expenditure before and after land conversion in the 5 villages covered by the survey had an average of Rp3,226,338 per month Rp3,376,121 per month, respectively. Of farmer household expenditure before land conversion, 46 percent was expended on food stuffs. Nonetheless, farm household expenditure after land conversion experienced a decrease of 1 percent. To the corollary, farmer household expenditure on nonfood stuff increased from 54 percent to 55 percent after land conversion.

Results of paired sample t-test to determine whether there is a significant difference in farmer household income per month before and after land conversion produced $\mathrm{T}$ statistic value of 3,418 with probability value of (0.001, significant) (Table 2). This implies that the null hypothesis is rejected. The inference is that there is a significant difference in income per month for farmer households in the 5 villages in Temon sub district who were affected by land conversion. To that end, results of paired sampled t-test showed that land conversion has significant influence on income per month of farmer household in the 5 villages in Temon sub district, Kulon Progo district. Study findings corroborate findings by Purwaningsih, Sutomo, and Istiqomah (2015) which found a significant difference in income after land conversion. In fact, farmer household income decreased compared after land conversion. Study findings are also in line with Kamilah (2013) findings that showed that land conversion induced a decrease in income for respondents covered in the study. The decrease farm land was one of the factors that was attributable to farmer household income in the 5 villages in Temon sub district. The decrease in farm land could take the form of a decrease in area of farm land for the household or an entire loss of farm land for the household. In the 5 villages covered by the study, there were household s who lost possession of all farm land they had during land conversion as a consequence of preparations for construction and development of NYIA. Kulon Progo district government is currently trying to relocate farmers who were affected by the project new land. Nonetheless, farmers reject such offers citing the long distance of the new farm land from their homes. The decrease in income and loss of means of livelihoods for farmer households in the 5 villages, in Temon sub district, has increased their vulnerability to food insecurity. Food insecurity refers to the inability of a household to have access to and consume food in the quantity and quality that is sufficient in a certain period of time. This calculated food insecurity based on the share of expenditure on food items to total household expenditure. If the share of household expenditure on food is smaller than $60 \%$ of total expenditure, the household is declared food secure, while if share of expenditure on food is larger than 60 percent 


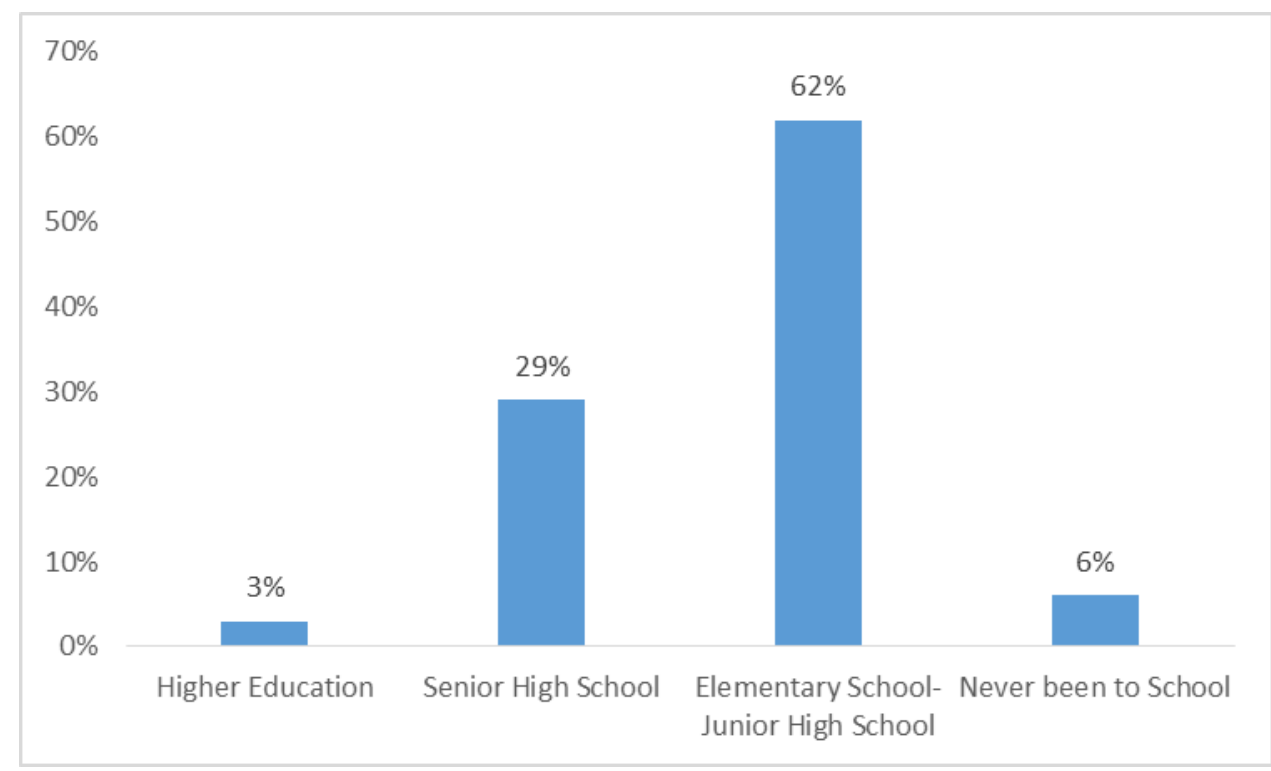

Figure 2. Percentage of respondents by education attainment in 5 villages in Temon sub district Source: Data analysis

of total household income that respective household is declared food insecure (Ilham and Sinaga, 2007). Based on that formulation, 87 percent and 90 percent of farmer households in the 5 villages in Temon sub district, Kulon Progo district were food insecure before and after land conversion, respectively (Figure 3 ). To that end, land conversion caused a three percent increase in the number of households that were vulnerable to food insecurity in the 5 villages in Temon sub district, Kulon Progo, district covered by the study.

\section{CONCLUSION}

The first conclusion is that land conversion was responsible for a decrease in farmer household income per month for households in the 5 villages in Temon sub district, Kulon Progo district who were affected by land conversion. Land conversion as part of the development of NYIA has forced some farmers to reduce the size of their farm land while others have had to lose all their farm land. Consequently, income of some farmer households decreased while not a few, due to strong dependency on farm income before land conversion, lost all the source of their income after land conversion. In other words, the construction and devel- opment of NYIA has already deprived some farmer households of their source of livelihood. The decrease in income by and large is attributable to a decrease in farm land and in some case, a total loss of al farm land. Attempts by Kulon Progo district government to mitigate the impact of land conversion on farmer household income by relocating affected farmers to new farm land, have received negative farmer response due to the long distance farmers have to travel from their homes. Consequently, the decrease in farmer household income has contributed to an increase in the number of farmer household that are vulnerable to food insecurity in the 5 villages covered in the study. While the number of farmer households vulnerable to food insecurity was 87 percent, after land conversion that number increased to 90 percent of all households-a 3 percent increase.

As regards advice, the authors recommend that Kulon Progo district government pay more attention to the adverse effects of land conversion on incomes and food security status of farmers in the 5 villages, Temon sub district, Kulon Progo district, affected by land clearance for the development of NYIA. To mitigate the impact, the local government should create alternative employment opportunities such as opening new small enterprises for households affected by 
Anisa Nurpita, Latri Wihastuti and Ike Yuli Andjani - The Impact of Land Conversion on Income....

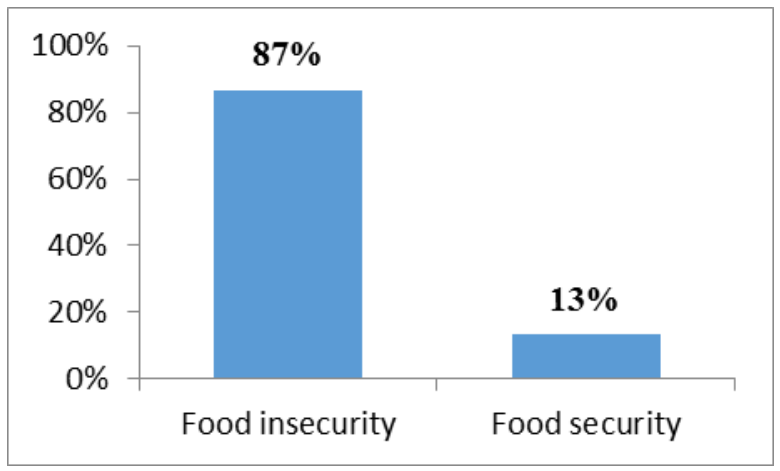

Before land conversion

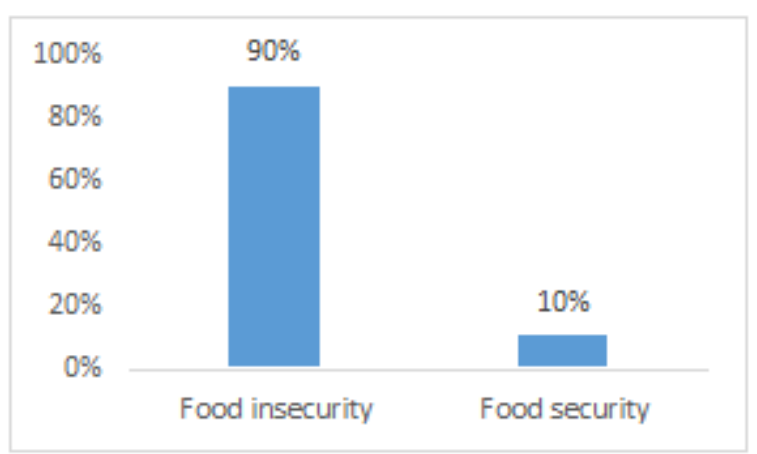

After land conversion

Figure 3. Percentage of farm household vulnerable to food insecurity before and after land conversion

Source: Data analysis

the project. Nonetheless, new job opportunities should reflect skillsets and competence of those affected. For farmers, who generally have low educational attainment, new job opportunities should be in the farming related activities. For instance, the government can relocate displaced farmers to the land that belongs to the district government with an additional condition that either famer households are also relocated or development of infrastructure and amenities is made in the new area prior to relocating displaced farmers. To mitigate the effect of an increase in food insecurity in the affected area, the local government should provide relief food supplies and other food subsidies in the short term to ensure that affected farmers can fulfil their food needs. Nonetheless, the long term solution to overcome an increase in the number of farmer households that are vulnerable to food insecurity in the 5 villages in Temon sub district, is for the local government to identify and create new sources of livelihoods.

\section{REFERENCES}

Badan Pusat Statistik. (2015a). Daerah Istimewa Yogyakarta dalam Angka 2015. BPS Daerah Istimewa Yogyakarta, 625. https://doi.org/10.1017/ CBO9781107415324.004

Badan Pusat Statistik. (2015b). Kabupaten Kulon dalam Angka Tahun 2015. BPS Kulon Progo.
Barwole, R. (1978). Land Resouece Economics. Prentile-Hall Inc:New Jersey.

Departemen Kesehatan. (2003). Gizi dalam Angka, sampai dengan Tahun 2002.

Genting, M. (2005). Faktor-faktor yang Mempengaruhi Alih Fungsi Lahan Pertanian Padi Sawah Terhadap Pendapatan Petani (Studi Kasus di Desa Munte Kabupaten Karo).No Title. USU Repository. USU Repository.

Ginting, M., Pascasarjana, P., \& Utara, U. S. (2007). Pendapatan Petani. Universitas Sumatera Utara:Medan, 2005-2007.

Hardinsyah. (2001). Pembangunan Pangan di Era Ekonomi Daerah Prosuding Dialog dan Loka Karya Kebijakan dan Program Pangan, Ketahanan Pangan di Era Ekonomi. Pusat Studi Kebijakan Pangan Dan Gizi IPB:Bogor.

Hendrawan, F. J. T. (2011). Analisis Dampak Alih Fungsi Lahan Pertanian Menjadi Kawasan Perumahan Terhadap Pendapatan Petani Dusun Puncel Desa Deket Wetan Lamongan. Universitas Negeri Surabaya:Jawa Timur, 1-10.

Hernanto. (1994). Ilmu Usahatani. Penebar Swadaya:Jakarta.

Ilham, N., \& Bonar, D. a N. (2007). Penggunaan Pangsa Pengeluaran Pangan Sebagai Indikator Komposit Ketahanan Pangan. SOCA (SocioEconomic of Agriculturre and Agribusiness), 7(3), 1-22. Retrieved from ojs.unud.ac.id/index.php/soca/ 
article/.../4217/3200

Kamilah, A. (2013). Analisis Ekonomi Alih Fungsi Lahan Pertanian di Kota Bekasi (Kasus Kecamatan Bekasi Utara dan Bantar Gebang). Jurnal Agribisnis Dan Pengembangan Wilayah, 5(1), 36-49.

Kartika, T. (2005). Analisis Coping Strategy dan Ketahanan Pangan Rumah Tangga Petani di Desa Majasih Kecamatan Sliyeg Kabupaten Indramayu. Institut Pertanian Bogor:Bogor.

Krejcie, Robert, \& Morgan. (1970). Determining Sample Size for Research Activities. Educational and Psychological Measurement, Vol 30: 60.

MacArthur, T., \& D, J. (1998). Social support \& social conflict. Www.macses.ucsf.edu/ Research/ psychosocial/notebook/socspp.

Martianto, D., \& Ariani, M. (2004). Analisis Konsumsi Pangan Rumah Tangga. Widyakarya Nasional Pangan Dan Gizi VII:Jakarta.

Maxwell, S., \& Frankenberger, T. R. (1992). Household Food Security: Concepts,Indicator, Measurements, A Technical Review. International Fund For Agricultural Development/United Nation Childrens Fund:Rome.

Mubyarto. (1989). Pengantar Ekonomi Pertanian. Lembaga Penelitian, Pendidikan dan Penerangan Ekonomi dan Sosial. Jakarta.

Mulyo, Irham, J., Widodo, \& Sugiyarto. (2009). Kajian Ekonomi Dampak Kenaikan Harga BBM terhadap Ketahanan Pangan Rumah Tangga Tani dan Rumahtangga Industri Rumahtangga Berbasis Produk Pertanian. KKP3T Badan Litbang Pertanian:Jakarta.

Nahib, I., \& Penelitian, P. (2013). Analisis Spasial Sebaran Ketahanan Pangan Di Kabupaten Lebak , Provinsi Banten. Pusat Penelitian, Promosi Dan Kerjasama Badan Informasi Geospasial:jakarta, 113-119.
Nasir, M. (2001). Metode Penelitian. Ghalia Indonesia:Bogor.

Organización de las Naciones Unidas para la Alimentación y la Agricultura (FAO). (2002). Measurement and assessment of food deprivation and undernutrition. International Scientific Symposium Rome.

Purwaningsih, Y., Istiqomah, N., \& Sutomo, S. (2015). Analisis Dampak Alih Fungsi Lahan terhadap Tingkat Ketahanan Pangan Rumah Tangga Petani di Kabupaten Karanganyar Provinsi Jawa Tengah. AGRARIS: Journal of Agribusiness and Rural Development Research, 1(2), 98-107. https://doi.org/10.18196/agr.1213

Puryantoro, \& Sulisyaningsih. (2013). Dampak alih fungsi lahan terhadap pendapatan petani (. Universitas Abdurachman Saleh Situbondo.

Ruswandi, A. (2005). Dampak Konversi Lahan Pertanian Terhadap Perubahan Kesejahteraan Petani dan Perkembangan Wilayah. Institut Pertanian Bogor:Bogor.

Saliem, H., \& Ariani, M. (2016). Ketahanan pangan, konsep, pengukuran dan strategi.Forum Penelitian Agro, 20(1), 1224. Retrieved from http:// ejurnal.litbang.pertanian.go.id/ index.php/fae/article/view/4280

Soekartawi. (1995). Analisis Usahatani. Universitas Indonesia: Jakarta.

Sulistyawati, D. A. (2014). Analisis dampak alih fungsi lahan pertanian terhadap ketahanan pangan di kabupaten cianjur. Institut Pertanian Bogor:Bogor.

Utomo, M., \& Dkk. (1992). Pembangunan dan Pengendalian Alih Fungsi Lahan. Universitas Lampung:Lampung. 